\section{Morphological and Agronomic Variability among Cultivars, Landraces, and Genebank Accessions of Purple Passion Fruit, Passiflora edulis f. edulis}

\author{
Nohra Rodríguez Castillo \\ Department of Biology, Laboratory for Plant Physiology and Biochemistry, \\ National University of Colombia, Bogotá, Colombia
}

\author{
Daniel Ambachew \\ Department of Agricultural and Environmental Sciences, Tennessee State \\ University, Nashville, TN 37209
}

Luz Marina Melgarejo

Department of Biology, Laboratory for Plant Physiology and Biochemistry, National University of Colombia, Bogotá, Colombia

\section{Matthew Wohlgemuth Blair \\ Department of Agricultural and Environmental Sciences, Tennessee State University, Nashville, TN 37209}

Additional index words. morpho-agronomic descriptors, multi-site yield testing, phenotyping data, purple passion fruit accessions, trait characterization

\begin{abstract}
Global demand for juice of the purple passion fruit, Passiflora edulis f. edulis, is growing, making it a promising species for farmers to grow in the highland tropics, to which it is adapted. However, research centers and private companies have done little to produce new high-yielding varieties. The objective of the present study, therefore, was to evaluate the agronomic and morphological characteristics of 50 passion fruit genotypes across two different elevations and agro-ecological sites as a base for germplasm enhancement. Three groups of genotypes were commercial cultivars (8 genotypes), genebank accessions (8), and landraces (34) collected from throughout the highlands of Colombia. The locations were at $1800 \mathrm{~m}$ above sea level (masl) (Pasca), in a place where cultivation of passion fruits is common; and at 2500 masl (Susacón), at a higher elevation site compared with most commercial plantings equal to a new agroecology for cultivation of the crop. Results indicated that the mid-elevation site produced higher yields (kg fruit/ plant) than the high elevation site, although some landraces were highly productive there. Commercial cultivar and genebank accessions clustered together in a principal component analysis (PCA); while landraces showed high levels of variation in the trait descriptors with five different clusters. Therefore, landraces of purple passion fruit contained greater genetic diversity than commercial cultivars or the genebank, and breeding programs for the crop should use landraces to increase diversity of varieties available to producers and to further expand the crop to new regions, at higher elevations, or with different agro-ecologies.
\end{abstract}

South America is the center of diversity for most cultivated passion fruits of the Passifloraceae family. This includes the area between Colombia, Ecuador, and Venezuela to the north and Bolivia, Brazil, and Peru to the south. Many species exist in this region and have been used for fresh fruit, juice, seasoning, and medicines. The main cultivated fruit species are Passiflora alata Dryander, $P$. antioquensis Karst., $P$. cumbalensis (Karst.) Harms, $P$. edulis Sims, $P$. ligularis Juss., P. maliformis L., P. mixta L., $P$. pinnatistipula (Cav.) DC., P. popenovii Killip, P. quadranugularis L., P. tripartite (Juss.) Poir, and P. serrulata Jacq. (Patiño, 2002). The names of these crops range from indigenous to Spanish in origin, across a broad group of ethnographies in South America. Many are classified as Apincoya (Bolivia), Chupa (Ecuador), Chisiqui (Ecuador), Curubas (Colombia and Ecuador), Granadillas (Andes), Gulupas (Colombia), and Purupuru or Tintin (Peru). A large, gourdlike fruit called "Badea" in Spanish (originally "Batiha" from Arabic) is known as the "Tumbo" or "Wakinto" in its homeland (Ecuador and Peru). "Maracuyas" or "Parchas," originally from Brazil but found in the rest of South America and the Caribbean, are common names for hot-climate $P$. edulis var. flavicarpa passion fruits (Ocampo et al., 2012a). Within the Andes Mountains, the cooler climate variant $P$. edulis var. edulis is grown. The diversity of passion fruits across these many species is large (da Silva et al., 2017; Santos et al., 2014). Furthermore, even apart from this very substantial diversity of cultigens, several other completely wild species are used, and some may intercross with the domesticated and semidomesticated species just described (Batista et al., 2017).

Among the most important of the Passifloraceae species is $P$. edulis, which has two subforms, the yellow passion fruit, $P$. edulis f. flavicarpa, and the purple passion fruit, Passiflora edulis f. edulis. Both are found in Brazil, its presumed center of origin, and now most Spanish-speaking countries of the hemisphere as well (Cerqueira-Silva et al., 2014). Dispersal from the center of origin in Brazil is thought to be south through Paraguay to most of Northern Argentina, and north toward the Guyanas and Central America, and more recently to Africa and Asia (Liu et al., 2017; Matheri et al., 2016a, 2016b). The exact subregion of Brazil where this species originated is still under debate, perhaps being the Amazon, the northeast (Maranhao), or the southwest (near Bolivia). In any case, the species is known to be very widely dispersed in the Andes from Peru to Venezuela, including a principal region of diversity in Colombia.

However, a distinction must be made between the two subforms of $P$. edulis. In one case, with f. flavicarpa, the spread was recent; while in the other case, with f. edulis, the spread was long ago. More specifically, the yellow passion fruit was only recently introduced to northern South America as a cash crop (Ortiz et al., 2012). Its history in the region is about 60 to 70 years old, having been introduced by experiment stations in the 1950 s to inter-Andean valleys. The purple passion fruit, meanwhile, has been found as landraces in Colombia and Ecuador for many years. Adaptation of yellow passion fruit is at 500 to 1000 masl, while purple passion fruit landraces are grown at many altitudes, from 1500 to 2500 masl.

Given the climate requirements and fruit preferences on the local and world markets for passion fruit, purple passion fruit is mostly grown in tropical to subtropical areas of East Africa (Kenya, Tanzania, and Zimbabwe) and Latin America (Brazil, Colombia, Ecuador, and Peru). It is also grown to a large extent in Oceania (Australia and New Zealand) where the climate is adequately warm but mild. Indeed, the highest producers by volume are Brazil and Oceania, followed by East Africa and the remaining Latin American countries. The potential for increasing production in all these regions is high, especially in a diverse agricultural region such as the Andes (Jiménez et al., 2012; Ortiz et al., 2012).

The purple passion fruit has advantages of having high brix, as well as concentrated flavor and sugars, making it easy to move the fruit juice around the world as a concentrate or to a lesser extent as fresh fruit (Matheri et al., 2016a, 2016b). Many private sector 
juice beverage makers have set up processing plants in the regions of production around the world to elaborate mixed juices and flavored drinks and then export them abroad to developed countries, where the juice fits the interest in tropical blend juices. Local markets for purple passion fruit complement the export market given that this type of $P$. edulis (i.e., $\mathrm{f}$. edulis) is favored for fresh juices and ice cream made straight from the fruits. Compared with the yellow passion fruit (f. flavicarpa), the smaller purple fruits are sweeter and more aromatic, and usually preferred for fresh use or for making juices or concentrates (Isaacs, 2009). In addition, the egg-shaped small fruits transport better than yellow passion fruit and mature from green to purple in transport. Currently the worldwide production is used up in these sectors, suggesting that there is demand for increased production (Jiménez et al., 2012). This is the case even in countries where the crop is traditional, like Colombia (CEPASS, 2016).

The promotion of Latin American production of purple passion fruit requires an understanding of the germplasm available to each country, especially in the centers of origin and diversity. The higher prevalence of diseases and insects in this region mean that collections of landraces should be tested extensively. Conservation in genebanks should be practiced either in situ or ex situ. The evaluation of diversity for these collections and their utility as new varieties can be assessed. In the case of purple passion fruit from the Andes Mountains, few studies have catalogued the morphological diversity because the crop is hard to establish and maintain (Tangarife et al., 2009). However, molecular studies with easily extracted DNA have been common, with various types of genetic markers showing that diversity of

Received for publication 1 Oct. 2019. Accepted for publication 2 Dec. 2019.

Published online 13 May 2020

We are grateful to the Colombian funding agency, Colciencias; to the Universidad Nacional de Colombia (UNAL); and to Tennessee State University (TSU) for providing funding and support for this project. Colciencias is acknowledged for the student scholarship to NRC under the project entitled "Eco-physiology, Mineral Nutrition and Integrated Pest Management of Diseases and Pests of Avocado, Curuba, Purple Passion Fruit and Tree Tomatoes for Agronomic Management and Development of Commercially Valuable Products." This project, led by L.M.M., belongs to a network called the "National Network for Fruit Bioprospecting RIFRUTBIO" (contract 0459-2013). Evans Allen 1890s funding was used at Tennessee State University for M.W.B. (contract TENX-07), who was the supervisor of the student exchange program UNAL/TSU under a memorandum of understanding (2014-19). The project at UNAL had the Hermes code 37360 .

M.W.B. is the corresponding author. E-mail: mblair@tnstate.edu.

This is an open access article distributed under the $\mathrm{CC}$ BY-NC-ND license (https://creativecommons.org/ licenses/by-nc-nd/4.0/). the local germplasm of Colombia is high (Ortiz et al., 2012).

The objectives of this study were to evaluate the morphological diversity of purple passion fruit germplasm from three sources: 1) landraces collected in Colombia, 2) accessions selected from the national genebank, and 3) commercial cultivars. The agronomic performance of all the genotypes was also compared. The overall goal was to understand the variability in qualitative and quantitative plant traits and characteristics found in Colombian purple passion fruit germplasm for potential breeding programs. Breeding work is also ongoing in Brazil, mostly for yellow passion fruit (Fagne et al., 2014; Junqueira et al., 2006, 2013; Lenza et al., 2009; Moreira, 2009; Roncatto et al., 2014) and China and Kenya for purple passion fruit (Liu et al., 2017; Matheri et al., 2016a) with an emphasis on creating hybrids, improving fruit characteristics. or developing varieties that resist a number of diseases and pests.

\section{Materials and Methods}

Germplasm sources. A total of 50 Passiflora edulis f. edulis (purple passion fruit or Gulupa) genotypes were used in the study, all of them named as entries held at the Biology Department of Universidad Nacional (BUN). The largest subgroup consisted of 34 landraces that were collected from 11 of the 23 Departments of Colombia. The other subgroups included eight commercial cultivars also collected from production regions, and eight genotypes from the national genebank for purple passion fruit, which is held in Rionegro, Antioquia, by Agrosavia (Ex. Corpoica); and eight commercial cultivars. Geographical representation of landraces and commercial cultivars were two from Antioquia, six from Boyacá, two from Cauca, eight from Cundinamarca, seven from Huila, five from Nariño, four from Putumayo, two from Risaralda, two from Quindío, one from Santander, two from Santander del Norte, and one from Tolima.

Field experimental design. The field design for the experiments consisted of randomized complete block designs with six replications (plants) across two locations. Plot sizes were $2 \mathrm{~m}$ wide $\times 2.5 \mathrm{~m}$ long and involved planting on a trellis system made of wooden posts and metal wires, in uncovered open fields (as opposed to greenhouse culture, which is sometimes used in commercial production). Alleys were $2 \mathrm{~m}$ in width to separate the plots. Each plot contained one plant that at maturity generally covered the entire trellis of the plot and these were pruned to maintain their distance from their neighbors. Soil tests were made to determine the $\mathrm{pH}$ and any nutrient deficiencies, and these were corrected with locally available lime and macro- and micronutrient-containing fertilizer. Pest and disease controls were based on the best practices for commercial purple passion fruit production.

Field sites and their characteristics. Of the two locations, the first was in a field on the farm "Carolina" in the municipality of Pasca, located at geocoordinates lat. $4^{\circ} 18,671^{\prime} \mathrm{N}$ and long. $74^{\circ} 20,116^{\prime} \mathrm{W}$, on the Fusagasugá-Pasca-Cundinamarca highway at an altitude of 1800 masl. There is an average yearly temperature of $18{ }^{\circ} \mathrm{C}$ and average yearly humidity of $85 \%$. As this site was in the midaltitude tropics, neither humidity nor temperature varied much from day to day or across night and day. For example, maximum and minimum temperatures for day and night were 24 and $10{ }^{\circ} \mathrm{C}$, respectively. The other location was on the farm "Cartago" in the municipality of Susacón, located at the coordinates lat. $6^{\circ} 143^{\prime} \mathrm{N}$ and long. $72^{\circ} 41,563^{\prime} \mathrm{W}$, on the Susacón-SoatáBoyacá highway at an altitude of 2500 masl. There is an average yearly temperature of $14{ }^{\circ} \mathrm{C}$ and average yearly humidity of $75 \%$. As this site was at a higher altitude, the maximum and minimum temperatures were lower-at 20 and $6{ }^{\circ} \mathrm{C}$, respectively.

Trait measurements. A total of 92 morphological and agronomic descriptor traits were evaluated and measured for each plant in the experiment. These included 29 qualitative traits evaluated on a binary basis as present or absent; and 73 quantitative traits measured in length, weight, or diameter (Supplemental Tables 1 and 2). The plant organs and subparts observed were flowers (anthers, bracts, petals, pistil, sepals, stamens, and stigma), fruit (peduncle and wall), leaves (blades and petioles), seeds (wall), stems (nodes), stipules, and tendrils, based on the descriptors used by the Ministry of Agriculture and others (Castro et al., 2012; Crochemore et al., 2003; Nunes et al., 2017). Two normality tests were conducted for each trait: 1) Kolmogorov-Smirnov (K-S) and 2) Cramér-von Mises (C-vM) values.

Analyses of variance and trait repeatability. Quantitative traits were evaluated for descriptive statistics and normal distributions, and traits were used for analyses of variance (ANOVAs) by using the RWizard package (Guisande, 2014). In the analyses, the genotype $(\mathrm{G})$ effects were considered random while planting site location (L) effects were considered fixed. Means squares were broken down into components (Table 1) based on genotype, location, and replication in a Generalized Linear Model (GLM) using SAS versión 9.4 (SAS Institute, Cary, NC). A repeatability coefficient $(\gamma)$ was estimated from the results of the ANOVA for each trait according to the following formula from Goodman and Paterniani

Table 1. Variance components $\left(\sigma^{2}\right)$ for each level of the experiment evaluating the effects of location (L) and genotypes (G) as well as the interaction genotype $\times$ location $(\mathrm{GL})$.

\begin{tabular}{|c|c|c|}
\hline $\begin{array}{l}\text { Sources of } \\
\text { variation }\end{array}$ & Factor & MS \\
\hline Location (2) & MS5 & $\sigma^{2}+\mathrm{GR} \theta_{\mathrm{L}}^{2}{ }^{1 / g}$ \\
\hline Repetitions (6) & MS4 & $\sigma^{2}+\mathrm{G} \theta_{R L}^{2}$ \\
\hline Genotypes (50) & MS3 & $\sigma^{2}+R \sigma_{G L}^{2}+R L \sigma_{G}^{2}$ \\
\hline $\begin{array}{c}\text { Genotype } \times \\
\text { locations }\end{array}$ & MS2 & $\sigma^{2}+\mathrm{R} \sigma_{\mathrm{GL}}^{2}$ \\
\hline Experimental error & MS1 & $\sigma^{2}$ \\
\hline
\end{tabular}


(1969), $\gamma=\sigma_{\mathrm{G}}^{2} /\left(\sigma_{\mathrm{L}}^{2}+\sigma_{\mathrm{GL}}^{2}\right)$, approximating broad sense heritability for the genotypes. Where $\gamma \geq 1$, the genotype effect was more important than the location or genotype $\times$ location (GL) effect; but where it was $\leq 1$, the location and interaction effects were more important.

Diversity analysis. A Ward mixed linear model (MLM) was used to simultaneously combine the data from the qualitative and quantitative traits together to estimate genetic dissimilarity according to Gower (1971). Variance inflation factors (VIF) were estimated to determine which traits explained the major portion of variability. Subsequently we conducted a PCA using RWizard, where we also calculated Eigen vectors for the principal components and traits. Clustering of genotypes was then conducted with SAS v. 9.4 to build a dendogram showing their relationships. The ideal number of groups was tested with pseudo $F$ and pseudo $t^{2}$-tests in the same version of SAS as well. The quantitative trait values for each group were then compared with boxplots and by multidimensional scaling (MDS).

\section{Results}

Quantitative traits. Of the 73 quantitative, nonbinary (Supplemental Table 2) traits, 11 $(15 \%)$ were distributed normally and 62 $(85 \%)$ were not distributed normally. The normally distributed traits included length of leaf lobes, distance between leaf tips, length of sepals, diameter of the flower peduncle, petal length, petal size/area, length of dentate filaments, anther length, degrees brix of fruits, width of seed pericarp beneath seed pits/fovea, and percentage germination. The non-normally distributed traits were the remaining data. Significant differences (at $P<0.05$ ) were seen between locations for 35 quantitative traits. This represented $48 \%$ of the 73 traits measured. The following traits showed highly significant differences $(P<$ $0.0001)$ between locations: leaf area, days to flowering, transverse fruit diameter, longitudinal fruit diameter, fruit volume, average fresh fruit weight, average fresh fruit pulp weight, dry fruit pulp weight, number of fruits per plant, total weight of fruits per plant, one hundred fresh seed weight, and one hundred dry seed weight. Coefficients of variation (Cvs) for the traits that were highly significant varied from $6.6 \%$ to $30.8 \%$, depending on the site and variable measured (Table 2). Most of the trait $\times$ location combinations, including 21 out of 24 traits, had CVs over $10 \%$; while only five out of 24 had CVs over $20 \%$. CVs of $30 \%$ or above, and resulting wide ranges in dispersal, were observed for length of tendrils, stipule length, and flower dry weight. Across locations, 60 out of 73 traits had overall cvs higher than $10 \%$ but lower than $30 \%$. When comparing locations, most values for length, diameter, and area or volume of stems, leaves, flowers, or fruits were higher in Pasca than in Susacón, indicating more favorable conditions in the mid-elevation site. Plant growth was faster in Pasca than in Susacón, as seen in the number of days for the vines to grow to a height of $2 \mathrm{~m}$, as well as other traits measured in terms of plant biomass. Although fruit volume was higher in the lower elevation site $\left(116.8 \mathrm{~cm}^{3}\right)$ than in the higher elevation site $\left(79.08 \mathrm{~cm}^{3}\right)$, the overall fruit number and fruit yield were similar, with 52 fruits/plant and $2.6 \mathrm{~kg} / \mathrm{plant}$, respectively, in Pasca, and 63 fruits/plant and $2.7 \mathrm{~kg} /$ plant in Susacón.

Differentiating traits and germplasm groups. The ANOVAs showed high significance $(P<0.001)$ of genotypic effects for leaf area, days to flowering, longitudinal and transverse fruit diameters, fruit volume and fresh weight, fresh and dry weight of fruit pulp, number of fruits and fruit weight harvested per plant, fresh and dry one hundred seed weight, and angles of seed vertices. Significant $(P<0.05)$ differences were still found for stipule length, diameter and length of the petioles, sepal length, diameter of the floral peduncle, fruit lid or operculum diameter, dentate filament length, number of seed pits, seed area, volume, and germination. Genotype $\times$ location effects were generally significant or highly significant.

Tukey's mean separation was used for comparing the average values of traits across the three groups of genotypes consisting of the commercial cultivars, the genebank accessions, and the landraces. In this case, highly significant $(P<0.0001)$ differences were observed for most traits, with greater mean separations between landraces and the other two groups than between the commercial cultivars and genebank accessions - this being a function of greater variability in the former group compared with the two latter groups, not necessarily better performance in terms of plant biomass or productivity.

Trait correlations and genotype variability. Highly significant $(P<0.001)$ linear correlations were observed among many of the traits, including positive correlations of $r \geq 0.7$ for number of seed pits with percent seed germination; for leaf area with fruit volume and diameters, as well as seed weight; and ligular filament length with style length. Negative correlations of $r \leq 0.7$ were found for leaf area or leaf dimensions with fruit yield. Therefore, small leaves in a genotype were indicative of low adaptation and low productivity in terms of fruit yield for that genotype.

A principal component analysis was conducted to determine the traits that best reflected the variability among the genotypes (Fig. 1). The first, second, and third components explained $41.7 \%, 21.2 \%$, and $7.8 \%$, respectively, of the observed variability in the diagram. Therefore, a total of $53.7 \%$ of variation was explained by the first three dimensions as calculated for Eigen vectors with the remaining variation explained by additional components and vectors (data not shown). The most important traits based on VIF analysis were days to flower, fruit brix percentage, titratable fruit acidity, fruit volume, and total fruit yield per plant, which together influences the definition of groups among the purple passion fruit genotypes.

Repeatability values. Repeatability values were derived from the ANOVAs for each of the 73 quantitative traits at both locations (Table 3 ). These varied according to the environment and the characteristic. High repeatability $(\gamma)$ reflected high genotypic effect, while low repeatability reflected low genotypic effect and high error. Among those traits with high repeatability were some of the seed traits, including pericarp thickness $(\gamma=$ $57)$, depth and number of seedcoat pitting $(\gamma=46.6, \gamma=1.89)$, seed length $(\gamma=55.5)$, seed width $(\gamma=7)$, seed volume $(\gamma=8.65)$, angle between seed vertices $(\gamma=3.39)$, hundred seed fresh weight $(\gamma=1.2)$, hundred seed dry weight $(\gamma=1)$, and the number of seed per fruit $(\gamma=1.21)$. Floral traits with high repeatability were stigma diameter $(\gamma=$ 8.9) and stipule length $(\gamma=10.5)$. Vegetative traits with high repeatability were central, lateral, and basal leaf lobes $(\gamma=5.9, \gamma=15$, $\gamma=5)$, peduncle diameter $(\gamma=58.9)$, and days to flowering $(\gamma=1.12)$. All other traits had repeatability values lower than one, showing that they had more environmental effects and error.

Qualitative traits. The group of qualitative traits (Supplemental Table 1) were evaluated in a binary manner for presence $(\mathrm{P})$ or absence (A). No differences were evident between locations or repetitions for the percentage values for $\mathrm{A}$ or $\mathrm{P}$ for the qualitative traits. Therefore, qualitative traits were stable and consistent between locations and plants of the same genotype. One of the principal differences observed between genotypes was the presence of anthocyanin coloration in the floral filaments, sepals, stems, stipules, or tendrils (BUN 016, 025, 033, 037), the presence of darker and more leathery leaves (BUN 036, 037, 038), or lighter colored (BUN 022, 032, 036, 040) or semielliptical seed (BUN 037, 009). Dark and fully elliptical seeds were the more common seed phenotype in the landraces.

Genotypes forming clusters. Examining the genotypes forming clusters showed that a total of six groups were defined based on cluster analysis and the genetic distance threshold shown in Fig. 2. Group 1 (G1) was made up of the 16 genotypes from the commercial and genebank sources, which clustered together. This group was characterized by having earlier maturing genotypes having the shortest days to flowering (264 d) and requiring the least time to reach the second wire of the trellis system (163 d). Despite being precocious, many of these genotypes had high leaf area indices, number of flowers, and yield per plant. As they were selected for cultivation, they also had larger fruit size, which was correlated with larger flowers and larger seeds.

All other groups in the dendogram of the 50 purple passion fruit genotypes were made up of landraces. In other words, the landraces were divisible into subgroups that were at the same level of grouping as the commercial and genebank types, which grouped together. First among these, Group 2 (G2), was made up of three landraces (BUN 027, 035, 046) and was characterized by thicker but shorter tendrils than other groups (average, $19 \mathrm{~cm}$ ), 
Table 2. Descriptive statistics for the most highly significant $(P<0.0001)$ traits evaluated in two locations, Pasca and Susacón, for the 50 purple passion fruit (Passiflora edulis Sims. var. edulis) genotypes used in this study.

\begin{tabular}{|c|c|c|c|c|c|c|c|c|c|c|c|c|}
\hline \multirow{2}{*}{$\begin{array}{l}\text { Quantitative } \\
\text { trait }^{z}\end{array}$} & \multicolumn{6}{|c|}{ Pasca (1800 masl) } & \multicolumn{6}{|c|}{ Susacón (2500 masl) } \\
\hline & Mean & Median & SD & Skewness & Kurtosis & $\mathrm{CV}$ & Mean & Median & SD & Skewness & Kurtosis & $\mathrm{CV}$ \\
\hline DF1 & 272.7 & 282.5 & 36.731 & -0.699 & -0.412 & 13.5 & 306.424 & 305.27 & 20.285 & 0.607 & 1.764 & 6.6 \\
\hline FR7 & 68.914 & 68.64 & 3.822 & 0.274 & -0.719 & 7.8 & 42.871 & 42.34 & 4.348 & 0.228 & -0.756 & 10.1 \\
\hline FR8 & 42.26 & 32.09 & 2.7 & 0.037 & -0.664 & 12.1 & 26.628 & 19.49 & 2.28 & 0.071 & -1.139 & 11.6 \\
\hline FR9 & 9.749 & 7.58 & 1.215 & 0.451 & -0.748 & 18.0 & 8.018 & 5.96 & 0.73 & -0.292 & -0.441 & 12.1 \\
\hline FR14 & 2.556 & 2.539 & 0.42 & -0.145 & -0.783 & 17.6 & 2.741 & 2.793 & 0.324 & -1.057 & 1.104 & 10.5 \\
\hline S7 & 1.8 & 1.72 & 0.001 & -0.022 & -1.201 & 20.8 & 1.2 & 1.13 & 0.001 & 0.484 & -0.344 & 15.2 \\
\hline S8 & 0.025 & 2.45 & 0.464 & 0.534 & -0.719 & 18.2 & 0.025 & 2.46 & 0.426 & 0.453 & -0.368 & 16.9 \\
\hline
\end{tabular}

${ }_{\mathrm{z}}^{\mathrm{L} 1}=$ leaf area $\left(\mathrm{cm}^{2}\right), \mathrm{DF} 1=$ days to flowering (days), FR1 = transverse fruit diameter $(\mathrm{cm}), \mathrm{FR} 2=$ longitudinal fruit diameter $(\mathrm{cm}), \mathrm{FR} 7=$ fresh weight per fruit $(\mathrm{g}), \mathrm{FR} 8=$ fresh fruit pulp weight $(\mathrm{g}), \mathrm{FR} 9=$ dry fruit pulp weight $(\mathrm{g}), \mathrm{FR} 10=$ number of fruits per plant $(\#), \mathrm{FR} 13=$ fruit weight per plot $(\mathrm{kg} / \mathrm{plot}), \mathrm{FR} 14=$ fruit weight per plant ( $\mathrm{kg} / \mathrm{plant}), \mathrm{S} 7$ = fresh hundred seed weight $(\mathrm{g}), \mathrm{S} 8=$ dry seed weight $(\mathrm{g})$.

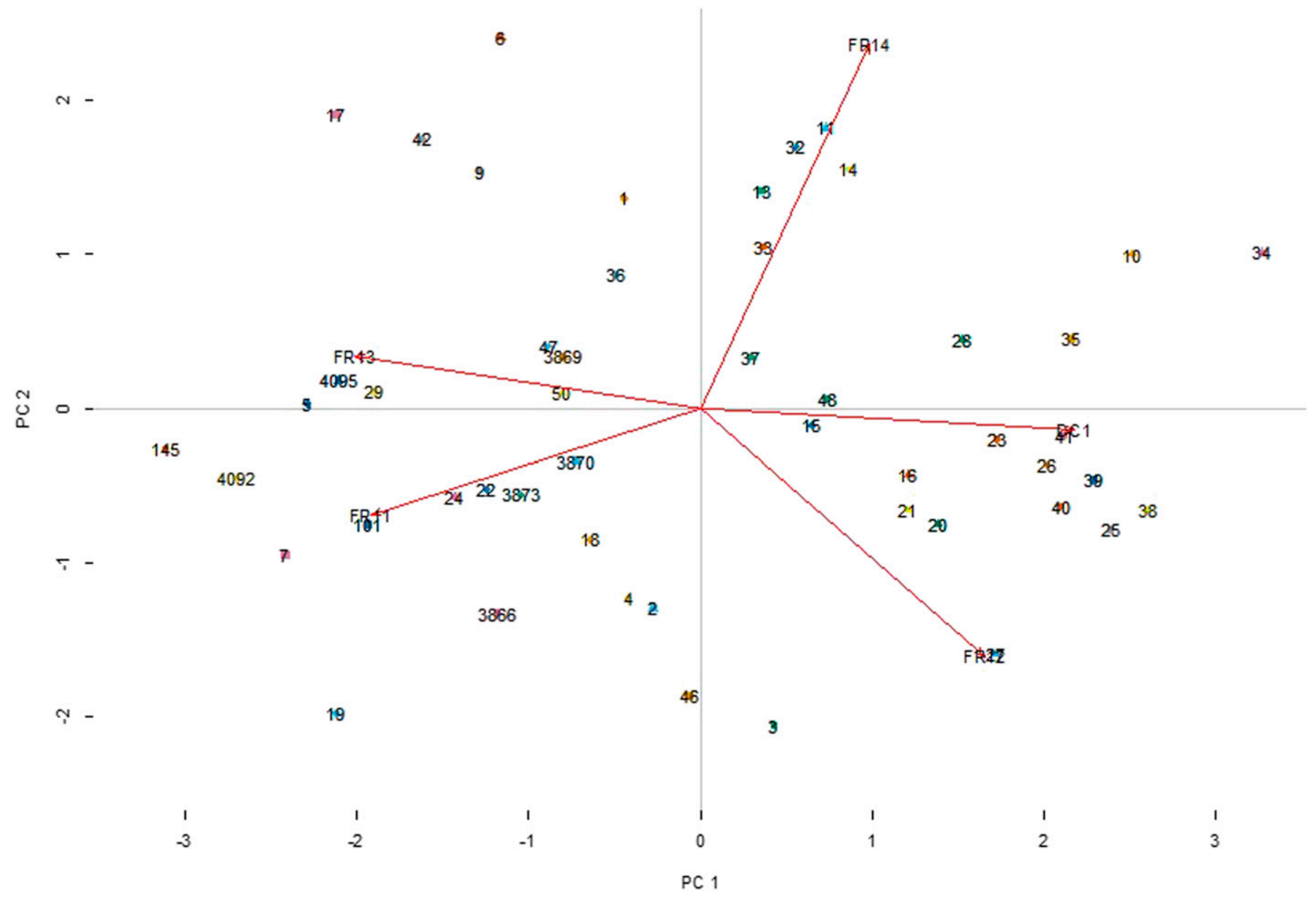

Fig. 1. Principal component analysis of $\mathrm{n}=50$ genotypes of purple passion fruit (Passiflora edulis var. edulis) based on 73 quantitative traits, showing the vectors for the five most important traits according to variance inflation factor (VIF) estimation: days to flowering (DF1), fruit brix percentage (FR11), titratable fruit acidity (FR12), fruit volume (FR13), and total fruit yield per plant (FR14). The components PC1 and PC2 explained 46\% and 37\%, respectively of the variation. Numbers in the graph represent individual accessions according to the list of genotypes.

with large leaf petioles $(2.8 \mathrm{~cm})$ and floral peduncles $(0.7 \mathrm{~cm})$, and higher titratable acidity (4.13) in their fruit. Group 3 (G3) was made up of 12 landrace genotypes (BUN 010, 016, 020, 021, 023, 025, 026, 028, 034, $038,039,040)$ characterized by having a longer lifecycle (316 d) and higher production (60 fruits per plant). Group 4 (G4) was made up of eight landraces (BUN 002, 003,
004, 015, 022, 024, 041, 048), which had thicker diameter stems, longer internodes between leaves, and little branching. Their fruit had high-grade brix (16\%) but produced less (47 fruit per plant). Group 5 (G5) was made up of different set of eight landraces (BUN 011, 013, 014, 032, 033, 036, 037, 047), which produced more seeds per fruit (186 seeds) and the highest yields (2.88 kg of fruit/plant). Group 6 (G6) was made up of three landraces (BUN 001, 006, 009) with higher leaf area indices, stem length and diameter, leaf and flower size, fruit volume, and number of seeds-but having slower growth $(212 \mathrm{~d})$, greater amount of seed pitting (74 pits per seed), a higher germination rate $(54 \%)$, better seed viability $(92 \%)$, and higher hundred fresh seed weight (2.1g) than 
Table 3. Variance components estimated for 73 quantitative traits evaluated for 50 purple passion fruit genotypes $\left(\sigma_{\mathrm{G}}^{2}\right)$ across two locations $\left(\sigma_{\mathrm{L}}^{2}\right)$ with genotype $\times$ location interaction $\left(\sigma_{\mathrm{GL}}^{2}\right)$ and repeatability coefficient $(\gamma)$.

\begin{tabular}{|c|c|c|c|c|c|c|c|c|c|c|c|}
\hline Variable & $\sigma_{L}^{2}$ & $\sigma_{G}^{2}$ & $\sigma_{\mathrm{GL}}^{2}$ & $\sigma_{\mathrm{e}}^{2}$ & $\gamma$ & Variable & $\sigma_{L}^{2}$ & $\sigma_{G}^{2}$ & $\sigma_{\mathrm{GL}}^{2}$ & $\sigma_{\mathrm{e}}^{2}$ & $\gamma$ \\
\hline $\mathrm{T} 1$ & 5.9 & 0.01 & 0.01 & 0.08 & 0.00 & F13 & 0.01 & 0.01 & 0.01 & 0.01 & 0.50 \\
\hline $\mathrm{T} 2$ & 384.2 & 1 & 3.7 & 10.34 & 0.00 & F14 & 0.01 & 0.01 & 0.01 & 0.01 & 0.50 \\
\hline T3 & 880.3 & 20.86 & 188.3 & 308.42 & 0.02 & F15 & 0.01 & 0.01 & 0.01 & 0.01 & 0.50 \\
\hline $\mathrm{Z1}$ & 34.7 & 0.43 & 3.54 & 13.21 & 0.01 & F16 & 0.01 & 0.01 & 0.01 & 0.01 & 0.50 \\
\hline $\mathrm{Z2}$ & 0.01 & 0.01 & 0.01 & 0.01 & 0.50 & F17 & 0.01 & 0.01 & 0.01 & 0.01 & 0.50 \\
\hline ST1 & 0.01 & 0.01 & 0.01 & 0.01 & 0.50 & F18 & 0.01 & 0.01 & 0.01 & 0.01 & 0.50 \\
\hline ST2 & 0.78 & 8.33 & 0.01 & 0.01 & 10.54 & F19 & 0.43 & 5.08 & 0.14 & 0.01 & 8.91 \\
\hline PE1 & 0.51 & 0.04 & 0.07 & 0.29 & 0.07 & DF1 & 101.5 & 267.05 & 136.11 & 62.56 & 1.12 \\
\hline PE2 & 0.01 & 0.01 & 0.01 & 0.01 & 0.50 & FR1 & 2.9 & 0.17 & 0.05 & 0.17 & 0.06 \\
\hline L1 & 87.2 & 217.57 & 653.63 & 214.25 & 0.29 & FR2 & 15.8 & 0.07 & 0.06 & 0.12 & 0.00 \\
\hline L2 & 3.3 & 24.95 & 0.91 & 6.65 & 5.93 & FR13 & 217.8 & 305.69 & 123.05 & 40.08 & 0.90 \\
\hline L3 & 0.1 & 16.83 & 1.02 & 5.2 & 15.03 & FR3 & 89.3 & 390.3 & 234.2 & 63.64 & 1.21 \\
\hline L4 & 0.72 & 13.55 & 1.97 & 5.44 & 5.04 & FR4 & 0.01 & 0.01 & 0.01 & 0.01 & 0.50 \\
\hline L5 & 1.02 & 0.14 & 1.38 & 6.86 & 0.06 & FR5 & 0.01 & 0.01 & 0.01 & 0.01 & 0.50 \\
\hline L6 & 11.8 & 0.38 & 0.7 & 9.19 & 0.03 & FR6 & 5.41 & 0.01 & 0.05 & 0.1 & 0.00 \\
\hline L7 & 3.72 & 0.09 & 13.66 & 39.17 & 0.01 & FR7 & 432.1 & 0.83 & 3.03 & 15.38 & 0.00 \\
\hline L9 & 0.25 & 0.28 & 0.93 & 2.66 & 0.24 & FR8 & 149.6 & 0.97 & 3.78 & 6.71 & 0.01 \\
\hline L10 & 0.38 & 0.23 & 0.54 & 0.43 & 0.01 & FR9 & 10.35 & 0.11 & 0.65 & 0.85 & 0.01 \\
\hline PED1 & 0.06 & 0.01 & 0.01 & 0.08 & 0.14 & FR10 & 169.8 & 10.37 & 31.64 & 64.27 & 0.05 \\
\hline PED2 & 0.01 & $4,476.7$ & 75.9 & 0.01 & 58.9 & FR11 & 2.15 & 0.03 & 1.01 & 2.2 & 0.01 \\
\hline SEP1 & 0.06 & 0.01 & 0.02 & 0.07 & 0.13 & FR12 & 0.01 & 0.02 & 0.16 & 0.26 & 0.12 \\
\hline SEP2 & 0.01 & 0.01 & 0.01 & 0.08 & 0.50 & FR14 & 0.48 & 0.01 & 0.04 & 0.17 & 0.02 \\
\hline SEP3 & 0.11 & 0.02 & 0.25 & 1.09 & 0.06 & $\mathrm{~S} 1$ & 6.03 & 52.09 & 21.42 & 14.15 & 1.89 \\
\hline PF1 & 0.01 & 0.01 & 0.01 & 0.01 & 0.50 & $\mathrm{~S} 2$ & 0.01 & 0.01 & 0.01 & 0.01 & 0.50 \\
\hline PF2 & 0.01 & 0.01 & 0.01 & 0.01 & 0.50 & S3 & 0.06 & 1.47 & 0.11 & 0.15 & 8.65 \\
\hline $\mathrm{F} 1$ & 0.01 & 0.01 & 0.01 & 0.01 & 0.50 & S4 & 6.22 & 0.11 & 1.36 & 2.4 & 0.01 \\
\hline $\mathrm{F} 2$ & 0.01 & 0.02 & 0.05 & 0.32 & 0.33 & S5 & 0.04 & 2.33 & 0.01 & 0.01 & 46.60 \\
\hline F3 & 0.01 & 0.01 & 0.01 & 0.05 & 0.50 & S6 & 0.01 & 1.14 & 0.01 & 0.01 & 57.00 \\
\hline F4 & 0.01 & 0.01 & 0.01 & 0.01 & 0.50 & S7 & 0.01 & 0.06 & 0.04 & 0.13 & 1.20 \\
\hline F5 & 0.01 & 0.01 & 0.01 & 0.02 & 0.50 & S8 & 0.02 & 0.03 & 0.01 & 0.03 & 1.00 \\
\hline F6 & 0.01 & 0.01 & 0.01 & 0.04 & 0.50 & S9 & 0.01 & 1.11 & 0.01 & 0.15 & 55.5 \\
\hline F7 & 0.01 & 0.01 & 0.01 & 0.01 & 0.50 & $\mathrm{~S} 10$ & 0.01 & 0.28 & 0.03 & 0.03 & 7.00 \\
\hline F8 & 0.18 & 0.01 & 0.07 & 0.16 & 0.04 & S11 & 89.6 & 386.1 & 24.2 & 164.8 & 3.39 \\
\hline F9 & 0.82 & 0.01 & 0.04 & 0.14 & 0.01 & S12 & 0.01 & 0.01 & 0.01 & 0.01 & 0.50 \\
\hline $\mathrm{F} 10$ & 0.01 & 0.02 & 0.1 & 0.01 & 0.18 & S13 & 261.79 & 18.55 & 87.09 & 99.86 & 0.05 \\
\hline F11 & 4.46 & 0.01 & 0.01 & 0.01 & 0.00 & S14 & 49.85 & 14.27 & 16.61 & 71.32 & 0.21 \\
\hline F12 & 0.03 & 0.02 & 0.05 & 0.3 & 0.25 & & & & & & \\
\hline
\end{tabular}

$\sigma_{\mathrm{e}}^{2}=$ error variance.

G1. The Ward MLM distance matrix between clusters (Table 4) found that G2 and G3 with G6 were most divergent (16.65 and 14.53, respectively); while G3 with G4 (6.21), G2 with G3 (8.0), and G2 with G4 (8.95) were most similar. Average within cluster distances were higher for G5 (3.8) and G6 (3.2) compared with G3 (2.1) and G4 (2.2).

After the clustering by PCA, multidimensional scaling was used to confirm the genotype groups found (Fig. 3). The MDS test was based on Kruskal method to determine the average deviation from the Gower's distance. A stress value threshold of $P \leq 0.2$ was used for validity of the adjustment. At an average of only $9 \%$ deviation, we found that the agronomic and morphological traits were valuable at grouping genotypes. The MDS results show that G1 and G6 formed the tightest clusters that were most easily distinguished. Meanwhile the other groups showed greater dispersion and higher similarity amongst themselves. For example, G3 and G4 genotypes were closely related. Finally, the landraces BUN 001, 006, and 009 (all from G6) were the most distinct of all the genotypes.

Box plots were used to compare the six groups for the variables most related to yield in passion fruits (Fig. 4). The time to flowering/growth period showed highly significant $(P<0.0001)$ differences between the groups, with G1 significantly earlier than the other groups and G3 significantly later. The degrees of brix (FR11) showed significant differences $(P=0.012)$ among groups, with $\mathrm{G} 4$ having the highest average and G6 having the lowest average, while $\mathrm{G} 2$ was very variable in brix content. Titratable acidity (FR12) also showed significant differences $(P=0.03)$, with G6 higher and G2 lower as inverse with brix content. Fruit volume (FR13) showed highly significant $(P<0.0001)$ differences among groups, with G1 and G6 being the most productive, followed by G5, with the other groups more variable but with similar intermediate averages. Total yield as measured by number of fruits per plant (FR10) and weight of fruits in $\mathrm{kg}$ per plant (FR14) showed significant $(P<0.01)$ differences among groups, with G6 and G5 again being superior to the other groups, G1 being the lowest yielding in weight, and G4 the lowest yielding in number of fruits per plant.

\section{Discussion}

Evaluation of the genotypes in the two contrasting locations used in this study allowed us to explore the variability or consistency of trait expression for agronomic and morphological characteristics of purple passion fruits. Results showed traits to be quite diverse across different environments, with plasticity in growth and production across growing sites, as has been observed before (Ocampo, 2005; Ocampo et al., 2010). Diversity assists in the adaptation of the species to many environments. It has been posited that passion fruit is a crop that is still in the process of domestication, given its inconsistent fruiting and low seed germination (Ortiz et al., 2012). Therefore, it is important to evaluate many traits, including leaf, flower, fruit, seed, tendril, and vine characteristics during diversity evaluations or breeding research.

Another aspect of our study was the use of three different groups of genotypes representing landraces, commercial types, and genebank accessions. We aimed to uncover possible redundancies in the new collections with previous ones or within the landrace group. However, morphotype duplication was low. Instead, we found that landraces represented a wealth of genetic diversity that was worth incorporating into breeding.

Despite some landraces showing lower yields than the commercial types, we believe that further exploration and collections of landraces is merited and worthwhile. We found landraces of purple passion fruit to be sources of adaptation to a new region of production like the high-altitude site of Susacón in Boyacá at 2500 masl compared with the commercial types, which did better in the standard region of production represented by 


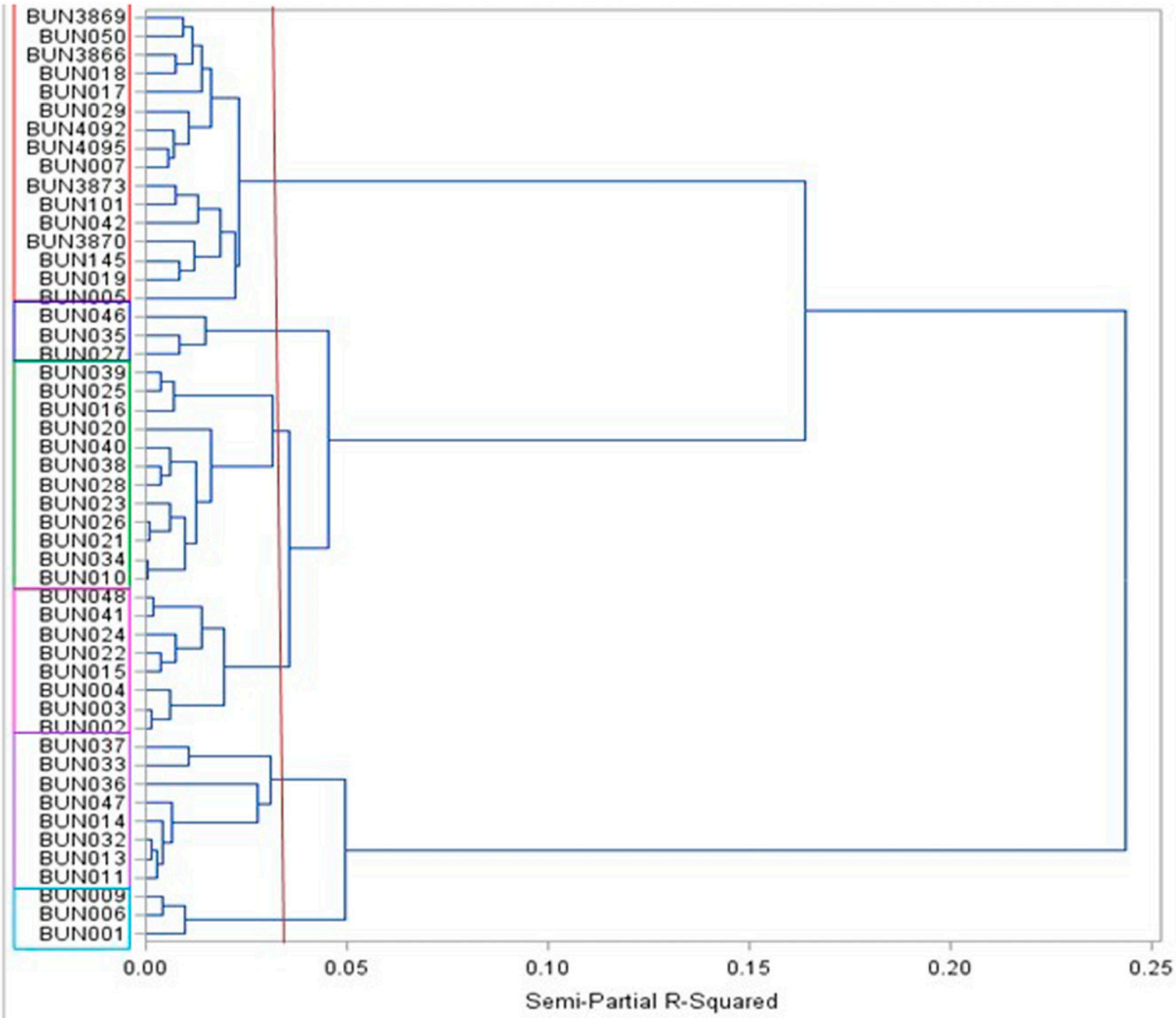

Fig. 2. Dendogram showing the clustering of 50 genotypes of purple passion fruit, Passiflora edulis f. edulis, which is evaluated in this study. Accession codes stand for the Biology department of the Universidad Nacional (BUN) of Colombia. Groups G1 to G6 are labeled to the left of the diagram. The $x$-axis scale is based on Gower's algorithm, based on genetic distance between genotypes, with a threshold of 0.0375 for distinguishing groups.

Pasca in Cundinamarca at 1700 masl. Similar results were found with photosynthetic parameters for these genotypes (Rodríguez et al., 2019). In addition, landraces and wild accessions are often the only source of resistances to the diseases that can decimate a long-season crop like passion fruit (Junqueira et al., 2004).

As climate change effects are felt, more high elevation adaptation will be needed. Indeed, expansion of purple passion fruit production into new agroclimatic regions and higher altitudes or latitudes is already occurring with the spread of the crop to East Africa highlands above 2000 masl (Matheri et al., 2016b) and to the subtropical mountains of southern China (Liu et al., 2017). In that regard, the higher elevation site of Susacón represents some new regions of production, having maximum and minimum average daily temperatures of 16.1 and $8.2{ }^{\circ} \mathrm{C}$, respectively. By comparison, Pasca had maximum and minimum average daily temperatures of 19.9 and $12.2{ }^{\circ} \mathrm{C}$, respectively. New regions have mostly been both cooler and drier and require supplemental irrigation. However, Susacón and Pasca had average monthly precipitation of 68 and $92 \mathrm{~mm}$, so neither site needed extra water other than rainfall. Solar radiation was not measured but given proximity to the equator, both locations had similar photoperiods of shortest days ( $11 \mathrm{hr} 46 \mathrm{~m}$ and $11 \mathrm{~h} 53 \mathrm{~m}$ ) and longest days $(12 \mathrm{~h} 29 \mathrm{~m}$ and $12 \mathrm{~h} 22 \mathrm{~m}$, respectively). One notable difference was in cloud cover, which was cloudy to mostly cloudy for $91 \%$ to $70 \%$ of the time in Pasca and $94 \%$ to $89 \%$ in Susacón. Wind speed was higher at the high elevation site $(7 \mathrm{~km} / \mathrm{h})$ than at the low elevation site $(6 \mathrm{~km} / \mathrm{h})$.

Selection of the best genotypes for each environment would be based on these and other climatic conditions of each site. For example, the higher elevation site had a higher water deficit stress, if not drought per se. The lower elevation site was more
Table 4. Distance between six clusters of purple passion fruits, calculated by the Ward MLM method. Number of genotypes for each group is shown in parentheses, and average withincluster distances are shown in the boxes on the diagonal in bold. $P$ value $=0.012$.

\begin{tabular}{|c|c|c|c|c|c|c|}
\hline \multirow[b]{2}{*}{ Cluster } & \multicolumn{6}{|c|}{ Distance between clusters } \\
\hline & No. G1 & G2 & G3 & G4 & G5 & G6 \\
\hline$\overline{\mathrm{G} 1}$ & (16) 2.2 & 12.36 & 11.2 & 10.65 & 12.08 & 12.48 \\
\hline G2 & (3) & 2.9 & 8.22 & 8.95 & 12.62 & 16.65 \\
\hline G3 & (12) & & 2.1 & 6.21 & 11.46 & 14.53 \\
\hline G4 & (8) & & & 2.2 & 10.15 & 13.36 \\
\hline G5 & (8) & & & & 3.8 & 10.78 \\
\hline G6 & (3) & & & & & 3.2 \\
\hline
\end{tabular}

favorable for high biomass production and overall passion fruit growth, and in a shorter growth period. This was seen for specific fast growth traits like the time to reach the second wire of the trellis system, as well as leaf area and the volume and weight of fruits produced. As fruits tended to be larger in Pasca, 

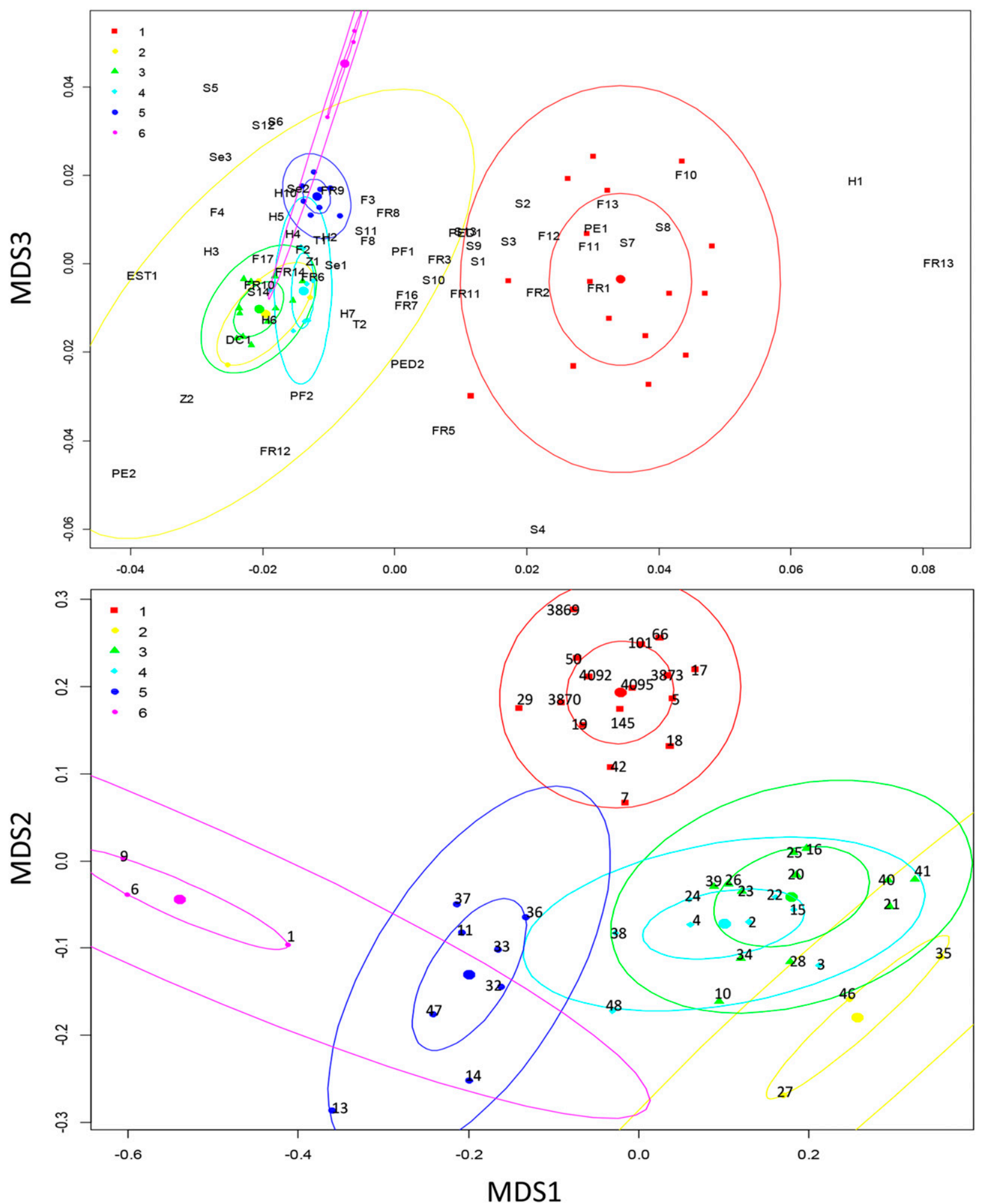

Fig. 3. Multidimensional scaling for 50 genotypes of purple passion fruit, Passiflora edulis f. edulis, grouped into six clusters found by the Ward MLM method, showing 1) their position relative to the traits and 2) their position relative to the groupings.

they were fewer in number than in Susacón. Similar results were found by Franco et al. (2014) and by Silva (2018), who noted that lower elevation sites favor fruit quality but not quantity, as each fruit is larger on average. The water stress conditions of the higher elevation site may mean that plants sacrifice leaf biomass to flower more prolifically, explaining why they would produce more but smaller fruits than at a lower elevation.

Grouping of genotypes according to their origin as landrace, commercial, or genebank accessions, was another aspect of our study. Landraces had wider diversity than commercial varieties. Narrow diversity in commercial purple passion fruit has been observed by various authors (Ocampo, 2007; Ortiz et al., 2012). We found a total of five subgroups within the landraces in our study based on morpho-agronomic characteristics, which shows that the semiwild purple passion fruits represent ample genetic diversity for breeding programs, as found before (CerqueiraSilva et al., 2015). Variability was mostly in 

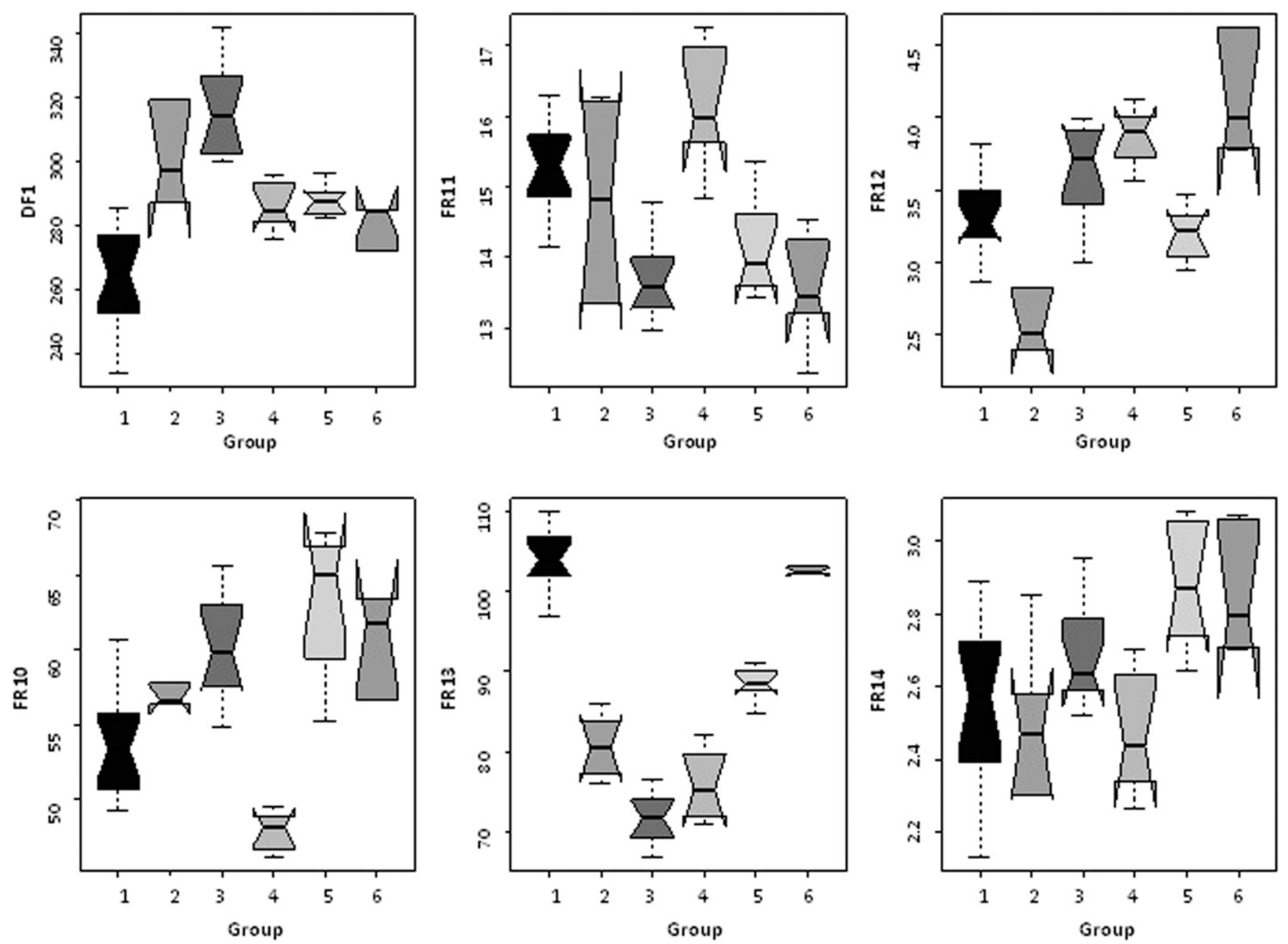

Fig. 4. Boxplot of six yield-related traits for 50 genotypes of purple passion fruit, Passiflora edulis f. edulis, comparing groups described in previous figures with varying numbers of accessions $(\mathrm{G} 1=16 ; \mathrm{G} 2=3 ; \mathrm{G} 3=12 ; \mathrm{G} 4=8 ; \mathrm{G} 5=8 ; \mathrm{G} 6=3)$. Trait abbreviations are $\mathrm{DC} 1=$ duration of growth curve; FR10 = number of fruits per plant; FR11 = degrees Brix; FR12 = titratable acidity; FR13 = fruit volume; FR14 = kg of fruits produced per plant.

flower and fruit characteristics for both purple passion fruits (Ocampo et al., 2012a) and yellow passion fruits (Lima et al., 2017). However, some differences have been noted by Costa (2016) in seed form, internode length, leaf size, and leaf hardness; with leaf differences possibly related to resistance and nonselection of passion fruit by the insect vector of Cowpea aphid-borne mosaic virus (CABMV). One similar study to ours found that landraces of yellow passion fruits, $P$. edulis f. flavicarpa, are also very diverse (de Lima et al., 2014).

Variation in passion fruit traits has also been observed for fruit volume, longitudinal diameter, and transversal caliper size (Fischer et al., 2009; Jiménez et al., 2012; Ocampo et al., 2012a; Pinzón et al., 2006). The widest fruits measured in those studies reached $8 \mathrm{~cm}$, while in our study the maximum value for diameter was $6 \mathrm{~cm}$. Seed length also varied between 1.4 and $4.3 \mathrm{~mm}$ in our study and between 3 and $6 \mathrm{~mm}$ in the study of Ocampo et al. (2012a). The similarity between studies for fruit diameter and seed length suggest these are highly heritable traits but with some environmental gradation (Lima et al., 2017).

Fruit quality, almost as much as fruit size, is another major issue for purple passion fruit breeding and selection. Brix content and titratable acidity are major factors, in addition to flavor and aroma, that affect the final sales price of the crop (Lima et al., 2017). Selection for fruit taste factors (such as sweetness, acid levels, color, and smell) in addition to fruit size has been in effect the past 20 to 30 years of fruit production (Ortiz et al., 2012). This has probably resulted in the narrowing of the genepool seen in the commercial types. Landraces had smaller fruit that were variable for sugar content as reflected by degrees of brix and acidity levels, probably reflecting variability in their flavor as well.

The final characteristics that varied among landraces and commercial types were their longer and thicker tendrils plus slower but longer vine growth. These traits would lead to plants with multiple vines that cling together for support. The tendrils especially would allow plants to grip to each other and to climb more vigorously. This would cor- respond to a process of natural selection by which plants invest in greater vegetative biomass for robust growth, which is especially important when the passion fruit accessions are competing with trees or shrubs for light, air, and water. Purple passion fruit landraces from coffee-growing regions tend to be long and viny, so as to grow up and amongst the understory bushes (including the coffee) or the shade trees used in traditional coffee production.

Packaging all the necessary traits together to obtain a highly productive and desirable purple passion fruit variety is a significant challenge. In group G4 we observed several landraces with longer internodes and low branching, which are easier to prune and therefore would reduce the labor requirements of the crop. These favorable characteristics were combined with high brix content comparable to or higher than that reported by Pinzón et al. (2006), Ocampo et al. (2012b), and Flórez et al. (2012). These would be ideal plants to analyze further, especially for higher photosynthetic capacity that might result from better leaf placement, and longer internodes that carry the leaves 
above the trellis and canopy for better exposure to available sunlight.

Group G5 was notable for having two landraces with different seed types that could reflect interspecific hybridization or diverse ancestry, as suggested by Bruckner and Otoni (1999) or da Cruz (2016), who also analyzed seed shape. Hybrid vigor in these plants may have been evident in the higher average yield of this group. Meanwhile, group G6 was ideal in terms of yielding ability but had fewer larger-sized fruits. This group's productivity may have been a result of high leaf area and active photosynthesis (Rodríguez et al., 2019). As an alternative, the longer dentate or ligulate filaments on flowers of these landraces may have encouraged insect pollinations and higher yield.

The need for pollinators in passion fruits is an important aspect of their evolution in the wild and could be a primary determinant of variation in leaf and flower characteristics (Ocampo and d'Eeckenbrugge, 2017). Increases in the size of certain flower structures of plants from the Passifloraceae family is often evidence of pollinator specificity and plant adaptation to specific insects (Kishore et al., 2010). Floral structure variation and floral organ size differences was described for wild and cultivated $P$. edulis by Ángel et al. (2011), Rendón et al. (2013), and Arias et al. (2014). A similar process of floral gigantism has been observed for the wild $P$. cincinnata species in Brazil (Piedade et al., 2010).

Other flower, leaf, and seed traits are also important from an evolutionary perspective. For example, variation in stigma size has resulted in andromonoecy in accessions of the temperate North American species $P$. incarnata (Krosnick et al., 2017). In various clades of Passifloraceae, leaves have been modified to have petiole or laminar nectaries that have coevolved with butterfly egg-laying behavior (de Castro et al., 2018; dell'Aglio et al., 2016). Leaf shape variation and "decorations" are also common attractants. Another characteristic differentiating wild and cultivated accessions of passion fruits is seed pitting. Fovaceous seedcoat depressions may be involved in higher water uptake (Rodríguez et al., submitted). Leaf traits can significantly influence productivity but interact with different hours of sunlight available at each location. Low solar radiation during rainy seasons can reduce plant and vine growth, and also the number of floral buds or open flowers (Paull and Duarte, 2012), while requirements for different passion fruits varies (Fischer et al., 2018). Mechanistic studies to see how seed and leaf characteristics are involved in cultivar productivity would be valuable, as these would be quite novel in comparison with other domestication traits.

\section{Literature Cited}

Arias, J.C., J.A. Ocampo, and R. Urrea. 2014. La polinización nativa en el maracuyá (Passiflora edulis f. flavicarpa degener) como un servicio reproductivo y ecosistémico. Agron. Mesoam. 25(1):73-83.
Batista, T., L. Semen, R. dos Santos, M. Moura, and P. Oliveira. 2017. Genetic diversity in accessions of Passiflora cincinnata mast. based on morphoagronomic descriptors and molecular markers. Rev. Caatinga, Mossoró 30:68-77.

Bruckner, C.H. and W.C. Otoni. 1999. Hibridação em maracuja, p. 379-399. In: Borém, A. (ed.). Hibridação artificial de plantas. UFV, Viçosa, Brazil.

Castro, J.A., C.G. Neves, O.N. Jesus, and E.J. Oliveira. 2012. Definition of morpho-agronomic descriptors for the characterization of yellow passion fruit. Scientia Hort. 145:17-22.

CEPASS. 2016. Corporación Centro de Investigación para la Gestión Tecnológica de Passiflora del Departamento-Huila. Boletín del Consejo Nacional de Pasifloras. Reunión trimestral Bogotá-Colombia.

Cerqueira-Silva, C., J. Onildo, E. Santos, R. Correa, and A. Souza. 2014. Genetic breeding and perspectives in molecular and genetics studies. Intl. J. Mol. Sci. 15:14122-14152.

Cerqueira-Silva, C.B.M., F. Gelape Faleiro, O. Nunes de Jesus, E.S. Lisboa dos Santos, and A. Pereira de Souza. 2015. The genetic diversity, conservation, and use of passion fruit (Passiflora spp.), p. 215-231. In: M.R. Ahuja and S. Mohan Jain (eds.). Genetic diversity and erosion in plants: Case histories. Springer, Switzerland.

Costa, S. 2016. Anatomia foliar e diversidade genética em Passiflora spp. (Passifloraceae 1.) resistentes a Cowpea Aphid-Borne Mosaic Virus (CABMV). Universidade Federal da Bahia Departamento de Biologia Geral Programa de Pós-graduação em Genética e Biodiversidade, Salvador, Brazil.

Crochemore, M.L., H.B. Molinari, and M.N. Stenzel. 2003. Agromorphological characterization of passion fruit (Passiflora spp.) germplasm. Rev. Bras. Frutic. 25:5-10.

da Silva, D., J. Peixoto, M. Souza, F. Gelape, K. Silva, R. De Deus, and I. Nogueira. 2017. Agronomic descriptors and ornamental potential of passion fruit species. Ornam. Hort. (Campinas) 23(3):357-362.

de Castro, É.C.P., M. Zagrobelny, M.Z. Cardoso, and S. Bak. 2018. The arms race between heliconiine butterflies and Passiflora plantsNew insights on an ancient subject. Biol. Rev. Camb. Philos. Soc. 93:555-573.

da Cruz, A. 2016. Parâmetros genéticos e estudo de adaptabilidade, estabilidade em híbridos de maracujazeiro-amarelo. Universidade Estadual de Feira de Santana, Departamento de Ciências Biológicas, Programa de Pós-graduação em Recursos Genéticos Vegetais, Brazil.

de Lima, F.H., A.P. Viana, R. Tavares, J. Cloviane, O. Freitas, J. Oliveira, and D. Lima. 2014 Measurement of genetic diversity in progenies of sour passion fruit by Ward MLM methodology: A strategy for heterotic group formation. Cienc. Agrotec. Lavras 38:240-246.

dell' Aglio, D.D., M.W. Losada, and C.D. Jiggins 2016. Butterfly learning and the diversification of plant leaf shape. Front. Ecol. Evol. 4:81

Fagne, E., D. Souza, M. Toledo, F. Galape, L. Borges, A. Barbosa, and S. Nietsche. 2014. Avaliação do desempenho agronômico de três genótipos de maracujazeiro-azedo sob cultivo irrigado no norte de Minas Gerais. FEPEG, Forum Ensino, Pesquisa, Extensao, Gestao. Unimontes, Brasil.

Fischer, G., F. Casierra-Posada, and W. Piedrahita. 2009. Ecofisiología de las especies de pasifloráceas cultivadas en Colombia. In: Cultivo, poscosecha y comercialización de las pasifloras en Colombia: Maracuyá, granadilla, gulupa y curuba. Sociedad Colombiana de Ciencias Hortícolas, Bogotá.

Fischer, G., L.M. Melgarejo, and J. Cutler. 2018. Pre-harvest factors that influence the quality of passion fruit: A review. Agron. Colomb. $36: 217-226$

Flórez, L.M., L.V. Perez, L.M. Melgarejo, and S. Hernandez. 2012. Caracterización fisicoquímica, fisiológica y bioquímica del fruto de gulupa (Passiflora edulis Sims), como indicadores para el punto óptimo de cosecha. In: L.M. Melgarejo (ed.). Ecofisiología del cultivo de la gulupa (Passiflora edulis Sims.). Universidad Nacional de Colombia. Produmedios.

Franco, G., J. Cartagena, and G. Correa. 2014. Análisis de crecimiento del fruto de gulupa (Passiflora edulis Sims), en las condiciones ecológicas del bosque húmedo montano bajo de Colombia. Revista de la U.D.C.A Act. \& Div. Cientifica 17(2):391-400.

Goodman, M. and E. Paterniani. 1969. The races of maize. III, Choices of appropriate characters for racial classification. Econ. Bot. 23:265273.

Gower, J.C. 1971. A general coefficient of similarity and some of its properties. Biometrics 27(4):857-871.

Guisande, C. 2014. RWizard software. University of Vigo, Spain. <http://www.ipez.es/RWizard>.

Isaacs, M. 2009. Mercados nacionales e internacionales de las frutas pasifloráceas. In: Cultivo, poscosecha y comercialización de las passifloráceas en Colombia: Maracuyá, Granadilla, Gulupa y Curuba. Sociedad Colombiana de Ciencias Hortícolas, Bogotá.

Jiménez, Y., C. Carranza, and M. Rodríguez. 2012. Gulupa (Passiflora edulis Sims.) In: G. Fischer (ed.). Manual para el cultivo de frutales en el trópico. Produmedios, Bogotá.

Junqueira, N.T., I.M. Icuma, M.C. Veras, M.A. Oliveira, and J.R. do Santos. 2013. Cultura do desempenho agronômico de cultivares maracujazeiro. SciTechnol 6:178-183.

Junqueira, N.T., D.A. Lage, M.F. Braga, J.R Peixoto, T.A. Borges, and S.R. Andrade. 2006. Reação a doencas e produtividade de um clone de maracujazeiro-azedo propagado por estaquia e enxertia em estacas herbáceas de Passiflora silvestre. Rev. Bras. Frutic. 28:831836.

Junqueira, N.T.V., M.F. Braga, F.G. Faleiro, J.R. Peixoto, and L.C. Bernacci. 2004. Potencial de especies silvestres de maracujazeiro como fonte de resistência a doenças, p. 80-108. In: F.G. Faleiro, N.T.V. Junqueira, and M.F. Braga (eds.). Maracujá: Germoplasma e melhoramento genético. Embrapa Cerrados, Planaltina.

Kishore, K., K.A. Pathak, R. Shukla, and R. Bharali. 2010. Studies on floral biology of passion fruit (Passiflora spp.). Pak. J. Bot. 42:21-29.

Krosnick, S., J. Perkin, T. Schroeder, L. Campbell, E. Jackson, S. Maynord, C. Waters, and J. Mitchell. 2017. New insights into floral morph variation in Passiflora incarnata L. (Passifloraceae) in Tennessee, U.S.A. Flora 236237:115-125.

Lenza, J.B., J.P. Valente, G. Roncatto, and L.A. Ching. 2009. Índice de pegamento e precocidade de mudas da variedade FB200 enxertada em diferentes especies silvestres e comerciais de maracujazeiro. Rev. Bras. Frutic. 31:831836.

Lima, R., A. Pio, E. Duarte, E. Azevedo, F. Higino, and C. Santos. 2017. Contribution of production and seed variables to the genetic divergence in passion fruit under different nutrient 
availabilities. Pesquisa Agropecuaria Brasilera, Brasília 52:607-614.

Liu, S., A.D. Li, C. Chen, G. Cai, L. Zhang, C. Guo, and M. Xu. 2017. De novo transcriptome sequencing in Passiflora edulis Sims to identify genes and signaling pathways involved in cold tolerance. Forests 8:435.

Matheri, F., M. Mwangi, S. Runo, M. Ngugi, D.T. Kirubi, A. Njoroge, A.M. Mawia, F.W. Kioko, R. Lagat, and N.A. Daniel. 2016a. Phenotypic characterization of selected Kenyan purple and yellow passion fruit genotypes based on morpho-agronomic. Adv. Crop Sci. Technol. 4:226.

Matheri, F., D. Nyamai, M.P. Ngugi, S. Runo, J.K. Njuguna, M. Mwangi, and D.T. Kirubi. 2016b. Phenotyping of selected Kenyan Passiflora edulis varieties and their hybrids based on quantitative morpho-agronomic traits. J. Hort. 3:181.

Moreira, P. 2009. Comportamiento agronómico de cinco poblaciones de maracuyá amarillo $(P$. edulis flavicarpa Degener), procedentes del Valle del Rio Portoviejo. Tesis pregrado Ingeniero Agrónomo. Universidad Técnica de Manabi, Facultad de Ingeniería Agronómica. SantaAna-Manabi, Ecuador.

Nunes, O., J. de Oliveira, F. Gelape, F. Soares, and E. Girardi. 2017. Illustrated morpho-agronomic descriptors for Passiflora spp. 1st ed. Embrapa, Brasília, DF.

Ocampo, J. 2005. Las frutas de la pasión en Colombia: Diversidad potencial como recurso genético. Centro Internacional de Agricultura Tropical, Cali, Colombia.

Ocampo, J. 2007. Study of the genetic diversity of genus Passiflora L. and its distribution in Colombia. Thesis Ph.D., Centre International d'Etudes Supérieures en Sciences Agronomiques-SupAgro Montpellier, France.

Ocampo, J. and G. d'Eeckenbrugge. 2017. Morphological characterization in the genus
Passiflora L.: An approach to understanding its complex variability. Plant Syst. Evol. 303:531-558.

Ocampo, J., C. Marin, C. Lopez, and A. Casas. 2012a. Manejo del cultivo de la gulupa. In: J. Ocampo and K. Wyckhuys (eds.). Tecnología para el cultivo de la gulupa (Passiflora edulis $\mathrm{f}$. edulis Sims) en Colombia. Centro de Biosistemas de las Universidad Jorge Tadeo Lozano, Centro Internacional de Agricultura Tropical, Ministerio de Agricultura y Desarrollo Rural, Bogotá

Ocampo, J., C. Marin, P. Posada, N. Lopez, and R. Solano. 2012b. Establecimiento y zonas productoras del cultivo de la gulupa. In: J. Ocampo and K. Wyckhuys (eds.). Tecnología para el cultivo de la gulupa (Passiflora edulis f. edulis Sims) en Colombia. Centro de Bio-sistemas de la Universidad Jorge Tadeo Lozano, Centro Internacional de Agricultura Tropical y Ministerio de Agricultura y Desarrollo Rural, Bogotá, Columbia.

Ocampo, J., K. Wyckhuys, M. Salazar, R. Solano, R. Urrea, M. Fonseca, and P. Posada. 2010. Restaurando la rentabilidad del maracuyá, la granadilla y la gulupa en Colombia por medio de mejoramiento genético participativo. Ministerio de Agricultura y Desarrollo Rural, Bogotá, Columbia.

Ortiz, D.C., A. Bohórquez, M.C. Duque, J. Tohme, D. Cuéllar, and T.M. Vásquez. 2012. Evaluating purple passion fruit (Passiflora edulis Sims f. edulis) genetic variability in individuals from commercial plantations in Colombia. Genet. Resources Crop Evol. 59:1089-1099.

Patiño, V. 2002. Historia y dispersión de los frutales nativos del neotrópico, vol. 326. Centro Internacional de Agricultura Tropical. Cali, Colombia CIAT.

Paull, R.E. and O. Duarte. 2012. Tropical fruits, vol. 2, p. 161-190. CABI, Wallingford, U.K.
Piedade, K.K., F. Medeiros, S. Pinheiro, E. Pitombeira, I. Araújo, and I. Borges. 2010. Biologia reprodutiva de Passiflora cincinnata Mast. (Passifloraceae) na região de Petrolina (Pernambuco, Brazil). Oecol. Australis 14:115-127.

Pinzón, I., G. Fischer, and G. Corredor. 2006. Determinación de los estados de madurez del fruto de la gulupa (Passiflora edulis Sims.). Agron. Colomb. 25:83-95.

Rendón, J.S., J. Ocampo, and R. Urrea. 2013. Estudio sobre polinización y biología floral en Passiflora edulis f. edulis Sims, como base para el premejoramiento genético. Acta Agron. 62:232-241.

Rodríguez, N.C., L.M. Melgarejo, and M.W. Blair. 2019. Purple passion fruit, Passiflora edulis Sims f. edulis, variability for photosynthetic and physiological adaptation in contrasting environments. Agronomy 9:231.

Roncatto, G., T. Kamel, and L. Saraiva. 2014. Avaliação de cultivares de maracuja-amarelo enxertadas em diferentes especies de maracuzeiro no estado do acre. Resultados de Pesquisas en EMBRAPA. 5273-5276.

Santos, E.A., A.P. Viana, J.C.O. Freitas, M.M Souza, C.L. Paiva, D.L. Rodrigues, and R.F. Tavares. 2014. Phenotyping of Passiflora edulis, $P$. setacea, and their hybrids by a multivariate approach. Genet. Mol. Res. 13:98289845.

Silva, K. 2018. Desempenho de híbridos brs de maracujazeiros em diferentes altitudes: Caracterização agronômica, ecofisiologia e alelopatia. Universidade Federal Do Espírito Santo Centro de Ciências Agrárias e Engenharias Programa de Pós-graduação em Produção Vegetal, Brazil.

Tangarife, M., C. Caetano, and C. Posada. 2009. Caracterización morfológica de especies del genero Pasiflora de Colombia. Acta Agron. 58:117-125. 
Supplemental Table 1. Qualitative traits (descriptors) with percentage frequency for phenotypic descriptors evaluated on plants of 50 genotypes of purple passion fruit (Passiflora edulis f. edulis). Letter and number codes were used to translate the characteristics into variables for statistical analysis.

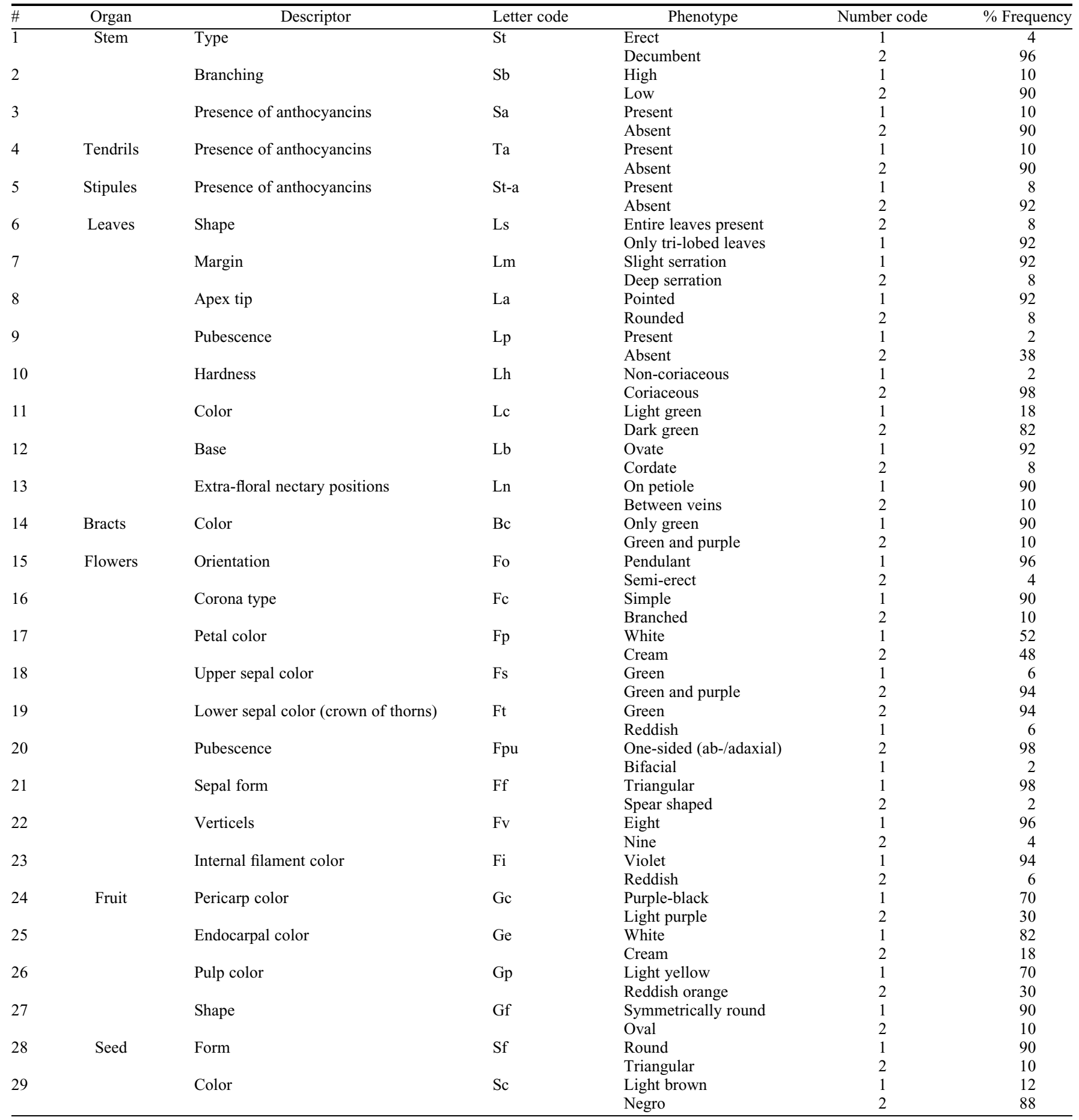


Supplemental Table 2. Quantitative traits, their unit of measurement and their abbreviated alpha-numeric code used to characterize 50 genotypes of purple passion fruit (Passiflora edulis f. edulis) landraces, varieties, and genebank entries in this study with results of analyses of variance showing significance ( $P$ value) for location, genotype and genotype $\times$ location effects along with variance inflation factor (VIF).

\begin{tabular}{|c|c|c|c|c|c|c|c|c|c|}
\hline \# & Trait & Unit & Alpha code & $\mathrm{KS}$ & CVM & $\frac{\text { Location }(\mathrm{L})}{P \text { value }}$ & $\begin{array}{c}\text { Accession }(\mathrm{G}) \\
P \text { value }\end{array}$ & $\frac{\mathrm{G} \times \mathrm{L}}{P \text { value }}$ & VIF \\
\hline$\overline{1}$ & Diameter stem & $\mathrm{cm}$ & $\mathrm{T} 1$ & $<0.01$ & $<0.005$ & $<0.0001$ & 0.89 & 0.0002 & 5.87 \\
\hline 2 & Distance internodes & $\mathrm{cm}$ & $\mathrm{T} 2$ & $<0.01$ & $<0.005$ & $<0.0001$ & 0.94 & $<0.0001$ & 3.26 \\
\hline 3 & Time to reach trellis height & days & $\mathrm{T} 3$ & $<0.01$ & $<0.005$ & 0.025 & 0.747 & $<0.0001$ & 4.89 \\
\hline 4 & Tendrils length & $\mathrm{cm}$ & $\mathrm{Z1}$ & $<0.01$ & $<0.005$ & 0.0047 & 0.313 & $<0.0001$ & 2.45 \\
\hline 5 & Tendrils diameter & $\mathrm{cm}$ & $\mathrm{Z} 2$ & $<0.01$ & $<0.005$ & 0.642 & 0.99 & $<0.0001$ & 2.25 \\
\hline 6 & Longitudinal length of stipules & $\mathrm{cm}$ & EST1 & $<0.01$ & $<0.005$ & 0.072 & 0.99 & $<0.0001$ & 2.29 \\
\hline 7 & Vertical length of stipules & $\mathrm{cm}$ & EST2 & $<0.01$ & $<0.005$ & 0.409 & 0.001 & 0.04 & 1.78 \\
\hline 8 & Petiole length & $\mathrm{cm}$ & P1 & $<0.01$ & $<0.005$ & 0.016 & 0.033 & $<0.0001$ & 1.12 \\
\hline 9 & Petiole diameter & $\mathrm{cm}$ & $\mathrm{P} 2$ & $<0.01$ & $<0.005$ & 0.097 & 0.0007 & $<0.0001$ & 3.23 \\
\hline 10 & Leaf area & $\mathrm{cm}^{2}$ & $\mathrm{H} 1$ & $<0.01$ & $<0.005$ & 0.0009 & $<0.0001$ & $<0.0001$ & 6.96 \\
\hline 11 & Central lobe length & $\mathrm{cm}$ & $\mathrm{H} 2$ & $<0.01$ & $<0.005$ & $<0.0001$ & 0.22 & 0.0009 & 1.15 \\
\hline 12 & Avg length of side lobes & $\mathrm{cm}$ & H3 & $>0.15$ & $>0.25$ & 0.0008 & 0.36 & $<0.0001$ & 1.23 \\
\hline 13 & Leaf base length & $\mathrm{cm}$ & $\mathrm{H} 4$ & $<0.01$ & $<0.005$ & 0.011 & 0.99 & $<0.0001$ & 6.59 \\
\hline 14 & Avg distance between lobe apices & $\mathrm{cm}$ & H5 & $>0.15$ & $>0.25$ & 0.32 & 0.67 & $<0.0001$ & 6.31 \\
\hline 15 & Avg lobular invagination distance & $\mathrm{cm}$ & H6 & $<0.01$ & $<0.005$ & 0.007 & 0.16 & 0.026 & 3.79 \\
\hline 16 & Divergence angle & degrees & $\mathrm{H} 7$ & $<0.01$ & $<0.005$ & 0.79 & 0.49 & $<0.0001$ & 3.06 \\
\hline 17 & Fresh leaf weight & $\mathrm{g}$ & H9 & $<0.01$ & $<0.005$ & 0.79 & 0.97 & $<0.0001$ & 4.65 \\
\hline 18 & Dry leaf weight & $\mathrm{g}$ & $\mathrm{H} 10$ & $<0.01$ & $<0.005$ & 0.04 & 0.93 & 0.013 & 1.25 \\
\hline 19 & Peduncle length & $\mathrm{cm}$ & PED1 & $<0.01$ & $<0.005$ & 0.04 & 0.13 & 0.016 & 1.56 \\
\hline 20 & Peduncle diameter & $\mathrm{cm}$ & PED2 & $<0.01$ & $<0.005$ & 0.08 & 0.47 & 0.51 & 1.54 \\
\hline 21 & Vertical length of sepals & $\mathrm{cm}$ & Se1 & 0.09 & 0.09 & 0.061 & 0.69 & $<0.0001$ & 6.19 \\
\hline 22 & Base length of sepals & $\mathrm{cm}$ & $\mathrm{Se} 2$ & $<0.01$ & $<0.005$ & 0.51 & 0.036 & 0.003 & 1.12 \\
\hline 23 & Sepal area & $\mathrm{cm}^{2}$ & $\mathrm{Se} 3$ & $<0.01$ & $<0.005$ & 0.84 & 0.62 & $<0.0001$ & 6.28 \\
\hline 24 & Floral peduncle length & $\mathrm{cm}$ & PF1 & $<0.01$ & $<0.005$ & 0.76 & 0.88 & $<0.0001$ & 1.63 \\
\hline 25 & Floral peduncle diameter & $\mathrm{cm}$ & PF2 & 0.1 & 0.2 & 0.085 & 0.023 & 0.029 & 1.54 \\
\hline 26 & Diameter flower bud at pre-anthesis & $\mathrm{cm}$ & F1 & $<0.01$ & $<0.005$ & 0.73 & 0.75 & 0.0007 & 1.58 \\
\hline 27 & Floral bud length at pre-anthesis & $\mathrm{cm}$ & $\mathrm{F} 2$ & $<0.01$ & $<0.005$ & 0.54 & 0.96 & $<0.0001$ & 7.79 \\
\hline 28 & Epicalyx length & $\mathrm{cm}$ & F3 & $<0.01$ & $<0.005$ & 0.22 & 0.5 & $<0.0001$ & 7.67 \\
\hline 29 & Unifacial process length & $\mathrm{cm}$ & $\mathrm{F} 4$ & $<0.01$ & $<0.005$ & 0.83 & 0.96 & $<0.0001$ & 7.02 \\
\hline 30 & Fresh weight per flower & $\mathrm{g}$ & F5 & $<0.01$ & $<0.005$ & 0.35 & 0.66 & $<0.0001$ & 4.13 \\
\hline 31 & Dry weight per flower & $\mathrm{g}$ & F6 & $<0.01$ & $<0.005$ & 0.41 & 0.63 & $<0.0001$ & 2.65 \\
\hline 32 & Petal width & $\mathrm{cm}$ & F7 & $<0.01$ & $<0.005$ & 0.4 & 0.53 & $<0.0001$ & 4.83 \\
\hline 33 & Petal length & $\mathrm{cm}$ & F8 & 0.14 & 0.24 & 0.09 & 0.95 & $<0.0001$ & 2.65 \\
\hline 34 & Petal area & $\mathrm{cm}^{2}$ & F9 & $>0.15$ & $>0.25$ & $<0.0001$ & 0.97 & $<0.0001$ & 6.17 \\
\hline 35 & Diameter of operculum & $\mathrm{cm}$ & F10 & $<0.01$ & $<0.005$ & 0.04 & 0.02 & 0.18 & 6.82 \\
\hline 36 & Long androgynous & $\mathrm{cm}$ & F11 & $<0.01$ & $<0.005$ & $<0.0001$ & 0.23 & $<0.0001$ & 2.14 \\
\hline 37 & Liguliform filament length & $\mathrm{cm}$ & F12 & $<0.01$ & $<0.005$ & 0.77 & 0.11 & $<0.0001$ & 2.54 \\
\hline 38 & Dentiform filament length & $\mathrm{cm}$ & F13 & $>0.15$ & $>0.25$ & 0.45 & 0.007 & $<0.0001$ & 6.11 \\
\hline 39 & Stamen length & $\mathrm{cm}$ & F14 & $<0.01$ & $<0.005$ & 0.34 & 0.27 & $<0.0001$ & 4.23 \\
\hline 40 & Anther length & $\mathrm{cm}$ & F15 & $>0.15$ & 0.09 & 0.91 & 0.76 & $<0.0001$ & 2.14 \\
\hline 41 & Style length & $\mathrm{cm}$ & F16 & $<0.01$ & $<0.005$ & 0.61 & 0.81 & $<0.0001$ & 2.14 \\
\hline 42 & Longitudinal ovary diameter & $\mathrm{cm}$ & F17 & $<0.01$ & $<0.005$ & 0.098 & 0.95 & $<0.0001$ & 4.71 \\
\hline 43 & Transverse ovary diameter & $\mathrm{cm}$ & F18 & $<0.01$ & $<0.005$ & 0.01 & 0.99 & $<0.0001$ & 4.20 \\
\hline 44 & Stigma Diameter & $\mathrm{cm}$ & F19 & $<0.01$ & $<0.005$ & $<0.0001$ & 0.17 & 0.0027 & 5.87 \\
\hline 45 & Time to maturity & days & DC1 & $<0.01$ & $<0.005$ & $<0.0001$ & $<0.0001$ & $<0.0001$ & 8.36 \\
\hline 46 & Transverse diameter of the fruit & $\mathrm{cm}$ & FR1 & $<0.01$ & $<0.005$ & $<0.0001$ & $<0.0001$ & $<0.0001$ & 2.14 \\
\hline 47 & Longitudinal diameter of the fruit & $\mathrm{cm}$ & FR2 & $<0.01$ & $<0.005$ & $<0.0001$ & $<0.0001$ & $<0.0001$ & 3.24 \\
\hline 48 & Fruit volume & $\mathrm{cm}^{3}$ & FR13 & $<0.01$ & $<0.005$ & $<0.0001$ & $<0.0001$ & $<0.0001$ & 7.45 \\
\hline 49 & Number of seeds per fruit & \# & FR3 & $<0.01$ & $<0.005$ & $<0.0001$ & 0.15 & $<0.0001$ & 4.73 \\
\hline 50 & Pericarp thickness & $\mathrm{mm}$ & FR4 & $<0.01$ & $<0.005$ & 0.46 & 0.68 & $<0.0001$ & 2.90 \\
\hline 51 & Thickness of the fruit wall & $\mathrm{cm}$ & FR5 & $<0.01$ & $<0.005$ & 0.005 & 0.91 & $<0.0001$ & 3.18 \\
\hline 52 & Peduncle length & $\mathrm{cm}$ & FR6 & 0.07 & 0.07 & $<0.0001$ & 0.5 & $<0.0001$ & 4.27 \\
\hline 53 & Fresh weight $\times$ fruit & $\mathrm{g}$ & FR7 & $<0.01$ & $<0.005$ & $<0.0001$ & $<0.0001$ & $<0.0001$ & 3.63 \\
\hline 54 & Fresh pulp weight per fruit & $\mathrm{g}$ & FR8 & $<0.01$ & $<0.005$ & $<0.0001$ & $<0.0001$ & $<0.0001$ & 5.48 \\
\hline 55 & Dry pulp weight per fruit & $\mathrm{g}$ & FR9 & $<0.01$ & $<0.005$ & $<0.0001$ & $<0.0001$ & $<0.0001$ & 2.54 \\
\hline 56 & Number of fruits per plant & \# & FR10 & $<0.01$ & $<0.005$ & $<0.0001$ & $<0.0001$ & $<0.0001$ & 7.14 \\
\hline 57 & Brix & degrees & FR11 & 0.09 & 0.11 & 0.12 & 0.56 & $<0.0001$ & 7.80 \\
\hline 58 & Titratable acidity & degree brix & FR12 & $<0.01$ & $<0.005$ & 0.59 & 0.29 & $<0.0001$ & 6.50 \\
\hline 59 & Fruit weight per plant & $\mathrm{kg} / \mathrm{plant}$ & FR13 & $<0.01$ & $<0.005$ & $<0.0001$ & $<0.0001$ & $<0.0001$ & 7.31 \\
\hline 60 & No. of seed pits per face & \# & $\mathrm{S} 1$ & $<0.01$ & $<0.005$ & 0.91 & 0.01 & $<0.0001$ & 9.68 \\
\hline 61 & Seed area & $\mathrm{mm}^{2}$ & $\mathrm{~S} 2$ & $<0.01$ & $<0.005$ & 0.49 & 0.004 & $<0.0001$ & 2.54 \\
\hline 62 & Seed volume & $\mathrm{mm}^{3}$ & $\mathrm{~S} 3$ & $<0.01$ & $<0.005$ & 0.39 & 0.007 & $<0.0001$ & 3.91 \\
\hline 63 & Seed pitting area & $\mathrm{mm}^{2}$ & $\mathrm{~S} 4$ & $<0.01$ & $<0.005$ & 0.027 & 0.68 & $<0.0001$ & 5.84 \\
\hline 64 & Seed pit depth & $\mu \mathrm{m}$ & S5 & $<0.01$ & $<0.005$ & 0.002 & 0.5 & $<0.0001$ & 1.21 \\
\hline 65 & Pericarp thickness at the alveoli & um & S6 & $<0.01$ & $<0.005$ & $<0.0001$ & 0.35 & 0.14 & 7.09 \\
\hline 66 & One hundred fresh seed weight & g & S7 & $<0.01$ & $<0.005$ & $<0.0001$ & $<0.0001$ & $<0.0001$ & 4.04 \\
\hline 67 & One hundred seed weight at $5 \%$ humidity & $\mathrm{g}$ & S8 & $<0.01$ & $<0.005$ & $<0.0001$ & $<0.0001$ & $<0.0001$ & 1.21 \\
\hline 68 & Horizontal seed length & $\mathrm{mm}$ & S9 & $<0.01$ & $<0.005$ & 0.36 & 0.25 & $<0.0001$ & 6.19 \\
\hline 69 & Vertical seed length & $\mathrm{mm}$ & $\mathrm{S} 10$ & $<0.01$ & $<0.005$ & 0.4 & 0.47 & $<0.0001$ & 5.72 \\
\hline 70 & Angle between vertices & degrees & S11 & $<0.01$ & $<0.005$ & 0.09 & $<0.0001$ & $<0.0001$ & 4.26 \\
\hline 71 & Pericarp thickness & $\mu \mathrm{m}$ & S12 & $<0.01$ & $<0.005$ & 0.03 & 0.61 & $<0.0001$ & 9.10 \\
\hline 72 & $\%$ seed viability & $\%$ & S13 & $<0.01$ & $<0.005$ & 0.06 & 0.93 & $<0.0001$ & 5.06 \\
\hline 73 & $\%$ germination & $\%$ & S14 & 0.1 & 0.47 & 0.09 & 0.008 & $<0.0001$ & 7.93 \\
\hline
\end{tabular}

